\title{
Nickel removal from electroplating waste water using stand-alone and electrically assisted ion exchange processes
}

\author{
I. Ismail • A. Soliman • N. Abdel-Monem • \\ H. Salah Ahmed $\cdot$ M. H. Sorour
}

Received: 30 October 2011/Accepted: 23 December 2012/Published online: 1 February 2013

(C) Islamic Azad University (IAU) 2013

\begin{abstract}
Wastewater discharged from metal-finishing processes usually contains nickel, a hazardous substance that is used extensively in the surface finishing industry. In the present study, an acidic solution containing nickel was treated using strong acid cation exchange resin. A continuous lab-scale cation exchange arrangement permitting the assessment of electric current as an enhancement mechanism was designed and utilized at different flow rates successfully. Applying the electrical potential enhanced the nickel removal by $12.7 \%$ at flow rate $240 \mathrm{ml} / \mathrm{h}$, and $2.5 \%$ at flow rate $500 \mathrm{ml} / \mathrm{h}$. Nickel recovery has been also investigated using hydrochloric acid as an eluent with and without electric current enhancement.
\end{abstract}

Keywords Industrial wastewater treatment · Nickel . Ion exchange $\cdot$ Electrically enhanced

\section{Introduction}

The release of heavy metals from industrial entities into the natural environment has led to serious pollution problems. Since these heavy metals are not biodegradable and can be biologically accumulated, their harmful effect on the environment lasts for long time. Among these different heavy metals, nickel is of high concern as it is extensively utilized in the modern industry. Direct exposition to nickel

I. Ismail $(\bowtie) \cdot A$. Soliman - N. Abdel-Monem - H. S. Ahmed Department of Chemical Engineering, Cairo University, Giza, Egypt

e-mail: dr_ismail@instruchem.org

M. H. Sorour

National Research Center, Giza, Dokki, Egypt cause dermatitis, while some nickel compounds are carcinogenic and easily absorbed by skin (Vieria et al. 2010).

Wastewater containing nickel originates from the metal processing industries, steel foundries, motor vehicle, aircraft industries, printing and some chemical industries. Nickel plating is used for plating parts to provide a corrosion protection finish. This coating is significantly thinner than hard-chrome plates, and is applied only in minutes rather than hours or days as required for hardchrome plating. The majority of nickel plating is done in an acidic medium, mostly in sulfate form, at $\mathrm{pH}$ value between 1.5 and 4.5 , and moderate temperature between 40 and $65^{\circ} \mathrm{C}$. These conditions highly affect the selection of the treatment process to be used for the removal of nickel from waste water (Popuri et al. 2009). Traditional processes usually utilized for nickel removal from waste waters are adsorption (Vieria et al. 2010; Popuri et al. 2009; Kandah and Meunier 2007; Li and Champagne 2009; Aguilar-Gonzalez et al. 2010; Ewecharoen et al. 2008), bio-sorption (Ozturk 2007; Bhatnagar and Minocha 2010), precipitation (Forstner and Wittman 1979), electrochemical methods (Dermentzis 2010; Akbal and Camci 2011; Kabadasli et al. 2009; Pospisil et al. 2008; Njau et al. 2000), filtration (Katsou et al. 2010; Borbely and Nagy 2009; Karate and Marathe 2008; Channarong et al. 2010), electroflocculation-filtration hybrid system (Sun et al. 2009), liquid-liquid extraction (Gonzalez et al. 2010) and ion exchange (Rengaraj et al. 2001; Alyuz and Veli 2009; Halle et al. 1982). In fact, ion exchange is a well-known technology that we have utilized in several difficult separation tasks up to isotope separation (Ismail et al. 1997a, 1997b, 2002, 2001; Fujii et al. 1998; Nogami et al. 2001). Due to its high efficiency, low operating cost, recovery of metal value, selectivity, absence of sludge, ease of operation and reaching the required discharge specifications, ion 
exchange method is highly preferable for nickel ions separation (Alyuz and Veli 2009). Although there are several inorganic ion exchanger and/or adsorbents capable of separating nickel ions from aqueous waste solutions, synthetic organic resins are commonly preferred due to its high performance and low cost. Halle et al. successfully utilized the macroporous carboxylic cation exchanger Wofatit CA-20, in sodium form, for the removal of nickel ions from aqueous solutions (Halle et al. 1982). Alyuz and Veli preferred the strong sulfonic cation exchanger Dowex HCR $\mathrm{S} / \mathrm{S}$ due to its high cation exchange capacity and managed to reduce the residual nickel and zinc in aqueous waste solutions below the discharge limits (Alyuz and Veli 2009). It was stated that more than $98 \%$ removal efficiency was achieved under optimal conditions for nickel and zinc.

Electrochemical ion exchange (EIX) is an advanced ion exchange process, where the ion exchange is enhanced by applying an electrical potential (Henry and Van Lierde 1998; Turner et al. 1989; Bridger et al. 2007; Coletta et al. 1997; Adams and Hudson 1991; Cumming et al. 1997; Ahmed Basha et al. 2008). The EIX can be used in several applications, e.g. the removal of toxic, heavy metal ions, the recovery of precious metals, water deionization, and corrosive anion removal. EIX is unique as the exchange processes are controlled electrochemically. The use of regenerating chemicals is, therefore, highly minimized and it is possible to achieve large volume reduction factors. The presence of the ion exchange material not only reduces the cell potential required, but also increases the contact area with the waste stream, thus enhancing the performance of the cell. Also, reversal of the applied electrical potential could, in principle, cause the elution of the metal ion by replacement with protons (Coletta et al. 1997; Adams and Hudson 1991).

The aim of the work was to study the different parameters affecting the removal of nickel ion from synthetic solution by ion exchange process, construct an electrochemical ion-exchange column, carry out both loading and regeneration cycles and study the performance of column in case of applying electric current.

\section{Materials and methods}

\section{Materials}

The chemicals used in this work were all of analytical grade. Distilled water was used to prepare the solution and to wash the glassware in each experimental run. The ion exchange resins used were Purolite C150S and AG MP-50 strong acid cation exchange resins. Table 1 shows the resins' specifications.

Preliminary batch tests

The following procedure was used to study the effect of several parameters on the uptake of nickel ions: a known weight of resin was added to a certain volume of solution having a known nickel concentration in a 50-ml bottle. Each sample was shaken for a certain time and then the test solution was filtered to separate the sorbent material from solution. The supernatant was analyzed and the residual concentration of the nickel ions in solution was determined.

\section{Electrochemical ion exchange cell}

A typical ion exchange column assembly was constructed as shown in Fig. 1. It consists of two cylindrical tubes: the outer has ID $80 \mathrm{~mm}$ diameter, and $500 \mathrm{~mm}$ length, while the inner tube has OD $32 \mathrm{~mm}$ diameter, and $650 \mathrm{~mm}$ length. There are two lead electrodes inside this column as shown in Fig. 1. The column was filled by $600 \mathrm{~g}$ of C-150S cation resin, which yields a bed height of $300 \mathrm{~mm}$.
Table 1 Specifications of the cation exchange resin

\begin{tabular}{|c|c|c|}
\hline Type & $\begin{array}{l}\text { Purolite } \mathrm{C} 150 \mathrm{~S} \text { (strong acid cation } \\
\text { exchange resin) }\end{array}$ & AG MP-50 \\
\hline Structure & $\begin{array}{l}\text { Macroporous resin of polystyrene } \\
\text { crosslinked with divenylbenzene }\end{array}$ & $\begin{array}{l}\text { Macroporous resin of polystyrene } \\
\text { crosslinked with divenylbenzene }\end{array}$ \\
\hline Active groups & $\mathrm{R}-\mathrm{SO}_{3}$ (sulphonic acid) & $\mathrm{R}-\mathrm{SO}_{3}$ (sulphonic acid) \\
\hline Ionic form & $\mathrm{Na}^{+}$(Sodium) & $\mathrm{H}^{+}$(hydrogen form) \\
\hline Particle size & $\begin{array}{l}0.42-1.2 \mathrm{~mm} \\
\leq 0.42 \mathrm{~mm}: 2 \% \max \\
\geq 1.20 \mathrm{~mm}: 2 \% \max \end{array}$ & $\begin{array}{l}100-200 \mathrm{mesh} \\
75-150 \mu \mathrm{m}\end{array}$ \\
\hline Effective size & $0.55 \mathrm{~mm}$ & Large \\
\hline $\mathrm{pH}$ range & $0-14$ & $0-14$ \\
\hline Shipping weight & Approx. $800 \mathrm{~g} / 1$ & Approx. $850 \mathrm{~g} / 1$ \\
\hline Supplier & PUROLITE & BIO-RAD \\
\hline
\end{tabular}




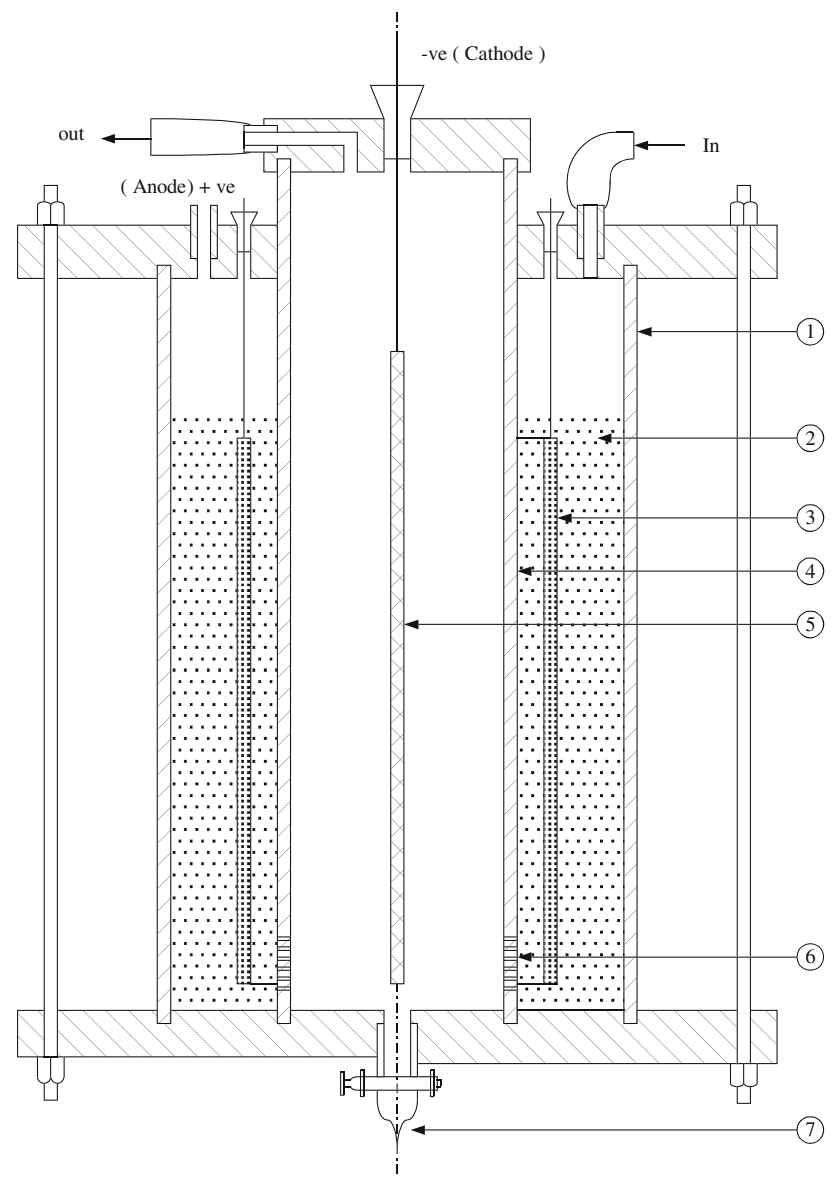

1- outer cylinder tube

2- Cation exchange resin

3- Lead-cylinder electrode (anode)

4- Inner cylinder tube

5- Lead-rod electrode (Cathode)

6- Teflon filter

7- Dreainage

Fig. 1 The electrochemical ion exchange setup

\section{Instrumentation}

All samples and chemicals used in the preparation of solutions were weighed using Sartorius analytical balance with a sensitivity of $10^{-4} \mathrm{~g}$. The $\mathrm{pH}$ of solutions was measured using Philips pH meter, model PW 9422. The electric current was supplied by DC power supply and was controlled using digital multi meter, New General model 400. The solutions were fed to the column using dosing pump, MILO ROYAL model DC-1-93R. Nickel ion concentration was measured using atomic absorption spectrophotometer model GBC-902.

\section{Experimental procedure}

The feed solution was passed through the annulus between the outer tube and the inner tube from the top through the anodic electrode and cation exchange resin. After that the feed passed through a Teflon filter at the bottom of the inner tube and then it passed from the bottom to the top of the inner tube through the cathodic electrode. The solution effluent from the top of the cell was fractionated and selected fractions were tested. Electric current between the anode and the cathode is applied and controlled by a DC power supply and multi meter.

\section{Results and discussion}

\section{Preliminary batch tests}

Figure 2 shows the percentage removal of nickel ions by the two resins at different solution volume to resin mass ratios, V/M. It is clear that in all cases the uptake behavior of $\mathrm{C}-150 \mathrm{~S}$ resin is better compared with AG MP-50. It was found that the uptake of nickel ions by $\mathrm{C}-150 \mathrm{~S}$ is
Fig. 2 Effect V/M on the removal of nickel ions by the two resins

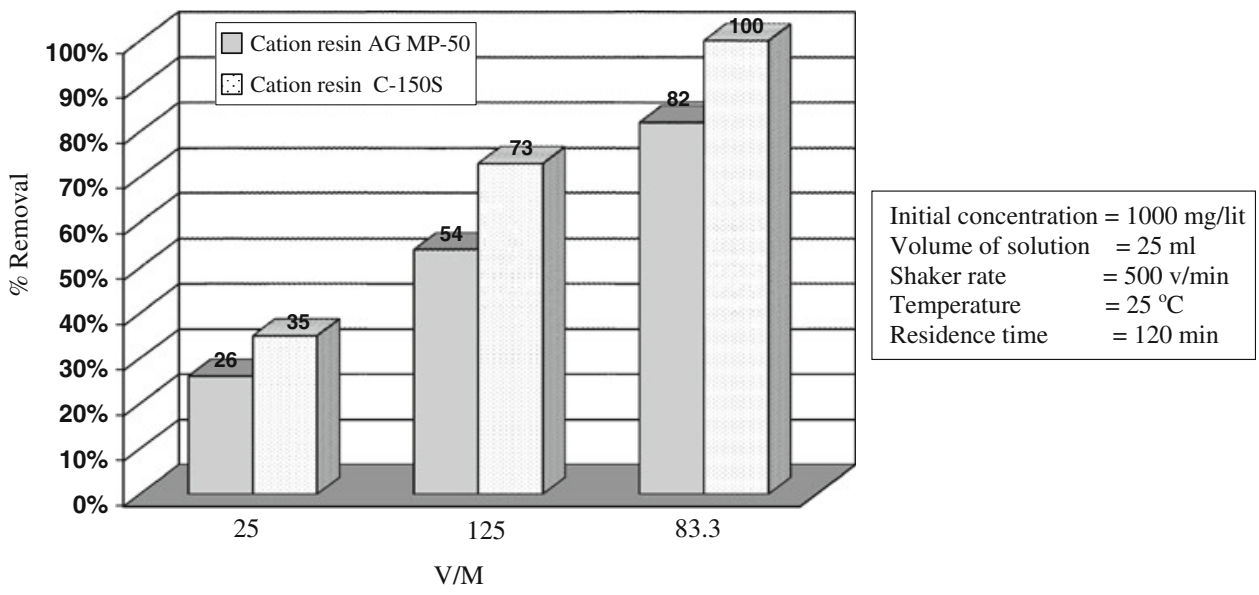


approximately $91 \mathrm{mg}$ of nickel ions/g resin, while it is only $68 \mathrm{mg}$ of nickel ions/g resin in case of AG MP-50. Therefore, C-150S resin was chosen to be used in continuous column operations.

\section{Effect of flow rate on breakthrough curve}

The most popular mode of operation of ion-exchange is the fixed bed mode. Therefore, it is essential to study this mode before implementing the proposed electrical enhancement process to compare the results and the performance criteria of the two schemes of operation. In this connection four break through runs were performed at different flow rates. If the breakthrough point is defined as the point at which the nickel concentration is $5 \mathrm{ppm}$, it is possible to measure the treated effluent volume for each run. Figure 3 shows the breakthrough curves obtained for different flow rates at the break point with concentration of $5 \mathrm{mg} / \mathrm{l}$ at each flow rate. It was found that the increase in flow rate decreases the volume of the treated solution at the break point, i.e. the capability of cation resin to remove the metal ion from the influent solution decreases as a result of the faster breakthrough, due to the decrease of residence time. Thus, the increase of flow rate decreases the contact time between solution and the cation resin in the column and hence residence time in the column. In other worlds, it increases the adsorption zone in the resin bed so the breakthrough of the nickel ions occurs earlier, i.e. increasing solution flow rate from $240 \mathrm{ml} / \mathrm{h}$ to $500 \mathrm{ml} / \mathrm{h}$ eventually reduces the efficiency from 80 to $60 \%$.

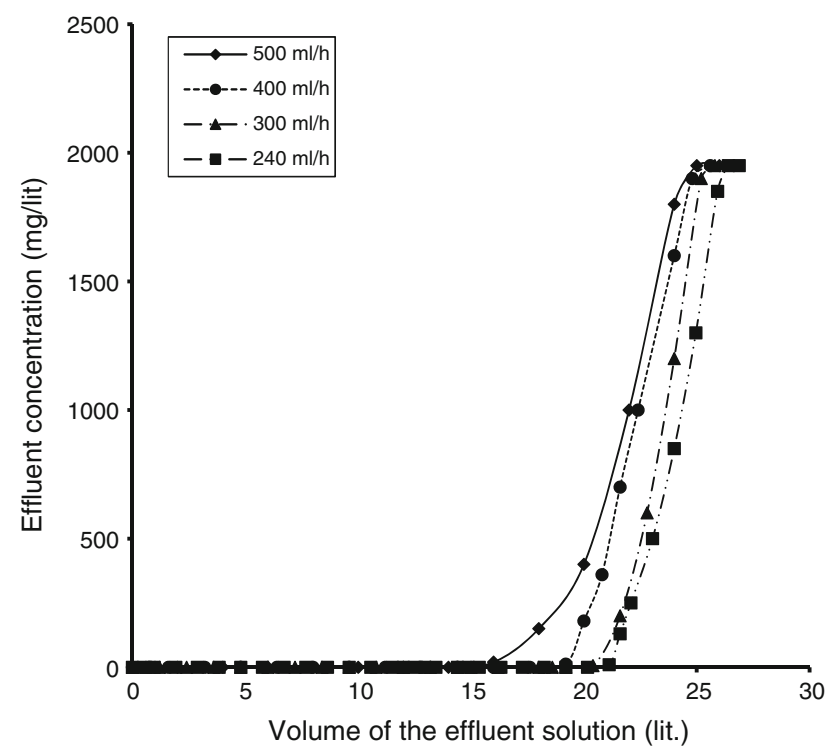

Fig. 3 Effect of flow rate on the breakthrough curves
Electrically Assisted Ion Exchange Process

The mechanism of the electrically assisted ion exchange process can be explained in its simplest form as follows (Cumming et al. 1997):

At the anode water is oxidized so that oxygen is formed with the release of protons:

$2 \mathrm{H}_{2} \mathrm{O} \rightarrow \mathrm{O}_{2}+4 \mathrm{H}^{+}+4 \mathrm{e}^{-}$

At the cathode hydrogen is evolved and hydroxyl ions are released by the reduction of water:

$2 \mathrm{H}_{2} \mathrm{O}+2 \mathrm{e}^{-} \rightarrow \mathrm{H}_{2}+2 \mathrm{OH}^{-}$

The release of hydroxyl ions at the working electrode produces a local $\mathrm{pH}$ rise, which de protonates the active ion exchange groups, so that cations are adsorbed to maintain charge balance. If the electrode polarity is reversed, protons are produced in the solution then they exchange with the adsorbed cations, i.e. the adsorbed cations are released as the exchanger reverts to its hydrogen form. The application of potential between the counter electrode and the working electrode causes cations to migrate from the solution to the structure of the resin. Within the ion exchange matrix the cations will exchange with protons that will continue to carry the current. Hydroxyl ions flowing in the opposite direction will form water as they associate with the protons. Of course some of the current may also be carried by cations migrating through the ion exchange material, from ion exchange sites to nearby neighboring sites. It is possible that some cations will reach the working electrode without being exchanged due to mass transfer limitations within the ion exchange matrix. If this occurs then these cations would leak from the rear of the cell and contaminate the treated effluent and breakthrough is achieved.

Effect of current intensity on $\mathrm{pH}$ value of the effluent solution

By increasing the current intensity, the evolution of $\mathrm{H}^{+}$ ions around the anode and the evolution of $\mathrm{OH}^{-}$ions around the cathode increase. As the anode area is so large compared with the cathode area, the concentration of $\mathrm{OH}^{-}$ ions around the cathode is much increased compared with the acidity around the anode (Aguilar-Gonzalez et al. 2010). Therefore, the $\mathrm{pH}$ value of the effluent increases with the increase of current intensity, until turbidity appears due to the formation of $\mathrm{Ni}(\mathrm{OH})_{2}$ at $\mathrm{pH}$ value above 6.5 according to Eq. (3).

$\mathrm{Ni}^{2+}+2 \mathrm{OH}^{-} \rightarrow \mathrm{Ni}(\mathrm{OH})_{2}$

Figure 4 shows the increase in the effluent $\mathrm{pH}$ with the increase in the current intensity. These results agree with 


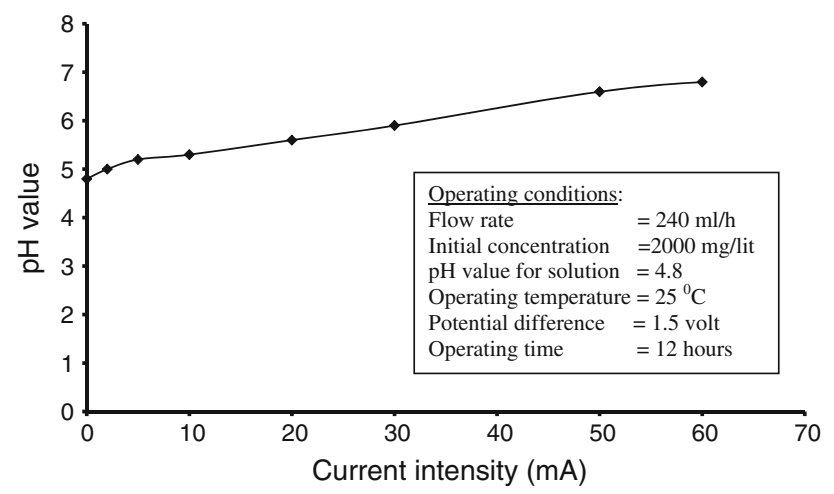

Fig. 4 Effect of current intensity on the effluent $\mathrm{pH}$ without resin

the results reported by C. Ahmed Basha et al. who studied the total dissolved solids removal by electrochemical ion exchange (EIX) process where, the $\mathrm{pH}$ of the effluent increased from an initial value of 7 to a maximum of 10.5 with due course of operation (Ahmed Basha et al., 2008). Such results were highly needed to determine the maximum working current, which was found to be $50 \mathrm{~mA}$.

Effect of $50 \mathrm{~mA}$ current intensity with influent flow rate variation

Figure 5 shows the breakthrough curves obtained at 240 and $500 \mathrm{ml} / \mathrm{h}$ flow rates in the absence and in the presence of $50 \mathrm{~mA}$ current intensity. Either in the case of normal ion exchange breakthrough, in absence of electric current, or in the case of electrically enhanced ion exchange breakthrough, the increase of flow rate decreased the effluent volume treated at break point. In both flow rate cases, the volume of the treated solution at the break point was increased upon applying the electric current as compared with the case of normal ion exchange process. At the low flow rate $240 \mathrm{ml} / \mathrm{h}$, the volume of treated solution, with $5 \mathrm{mg} / \mathrm{l}$, increases from 21 to $26 \mathrm{l}$, while the effect is relatively small in the case of high flow rate $500 \mathrm{ml} / \mathrm{h}$, where the volume of treated solution with $5 \mathrm{mg} / \mathrm{l}$ increases from 16 to $18 \mathrm{l}$. The amount of nickel ions removed was measured at the two flow rates in the case of applying current and in the absence of electric current and are shown in Fig. 6. The amount of nickel removed from the solution and sorbet by the resin at a flow rate of $240 \mathrm{ml} / \mathrm{h}$ was increased by $12.7 \%$ upon applying the electric current, while the increase of this amount at a flow rate of $50 \mathrm{ml} / \mathrm{h}$ due to electric current was only $2 \%$. This can be attributed to the mobility of ions in case of high flow rate; also the electric current

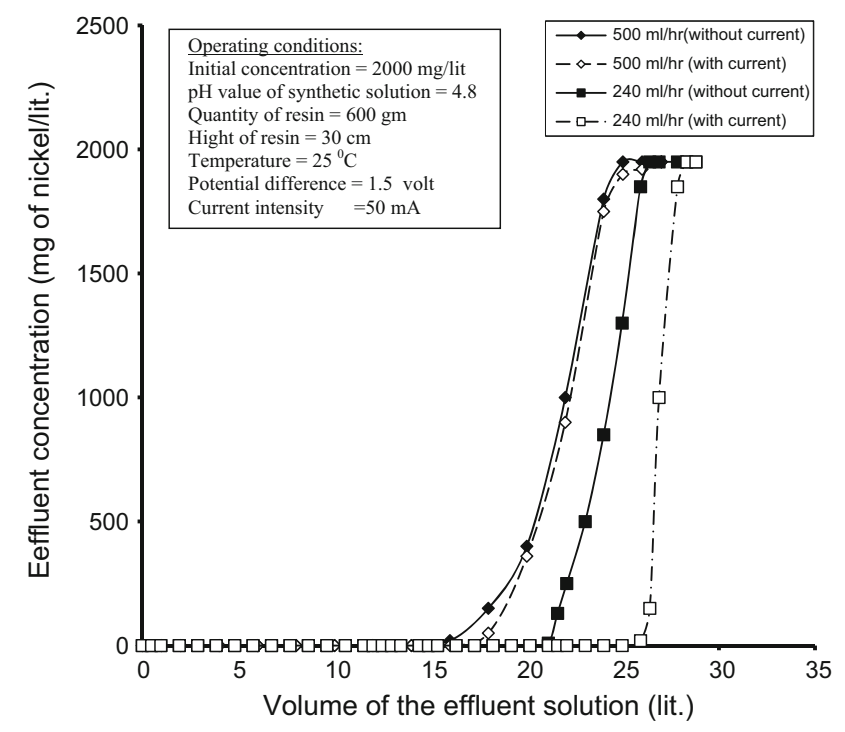

Fig. 5 Effect of current intensity on the breakthrough curves at different flow rates

increases the ion velocity and this in turn improves the mass transport and nickel removal.

Regeneration of cation resin and recovery of nickel ions

For any ion exchange process, regeneration is ultimately needed. The regeneration was carried out using hydrochloric acid. Reversing of polarity of the applied current and the utilization of different concentrations of hydrochloric acid were studied. Figure 7 shows the elution curve of nickel ions from the column by $2 \mathrm{M}$ hydrochloric acid solution in the presence and absence of reversed electrical current. It is noticeable that there is no much improvement due to electrical current compared with the case of nickel loading, i.e. the enhancement of electrical current is limited in case of high velocity as a result of lower residence time. The amount of hydrochloric acid used to elute nickel ions from the full-load resin bed was measured in the case of applying current and in the absence of electric current. The highest effluent concentration by regeneration with reversed potential is $11,000 \mathrm{mg} / \mathrm{l}$, but no more than $9800 \mathrm{mg} / \mathrm{l}$ was achieved in the absence of current. Most of the nickel will be eluted by the second and third liters of $2 \mathrm{M}$ hydrochloric acid, where more than $85 \%$ of eluted nickel is contained within $40 \%$ of the effluent. These two liters can be collected in storage tank for reuse, and the dilute quantity can be recycled to elute nickel ions or collected in a receiver tank to re-concentrate the nickel ions, i.e. about $40 \%$ of the $2 \mathrm{M}$ hydrochloric acid can be 
Fig. 6 Effect of current intensity on the amount of nickel ions removed at different flow rates

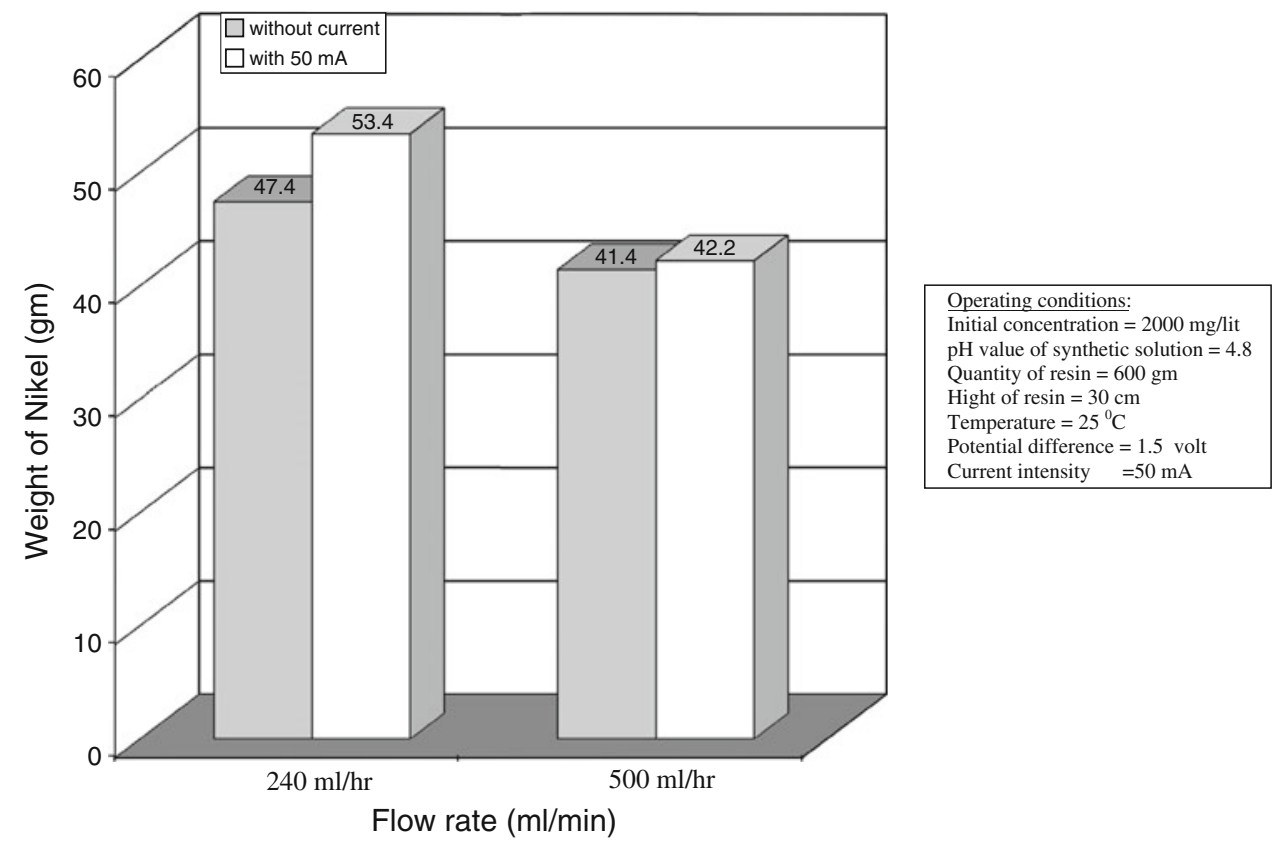

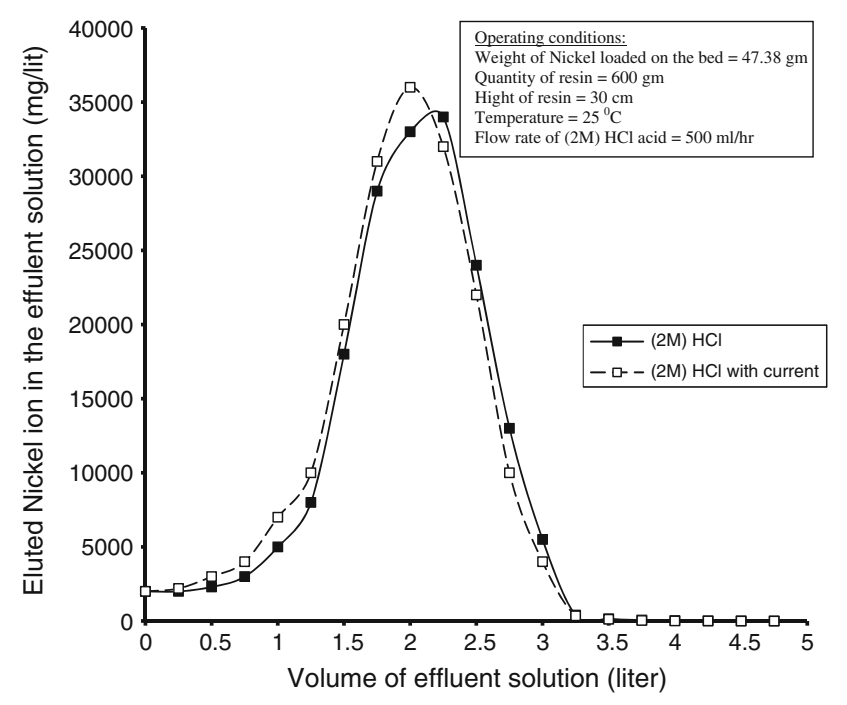

Fig. 7 Effect of current intensity on elution curves of nickel ions by $2 \mathrm{M} \mathrm{HCl}$

reused to initiate regeneration in the second regeneration cycle followed by a fresh $2 \mathrm{M}$ hydrochloric acid. This of course requires implementation of a monitoring system. Based on percentage removal data the regeneration cycle could be terminated using about 3.21 of $2 \mathrm{M}$ hydrochloric acid, and discarding the first portion of the elute nickel, thus permitting favorable conditions for recycle.

\section{Conclusion}

A synthetic solution resembling metal-finishing processes wastewater contaminated with nickel ions was treated using strong acid cation exchange resins. A continuous labscale cation exchange arrangement permitting the assessment of electric current as an enhancement mechanism was designed and utilized at different flow rates successfully. Applying the electrical potential enhanced the nickel removal by $12.7 \%$ at flow rate $240 \mathrm{ml} / \mathrm{h}$, and $2.5 \%$ at flow rate $500 \mathrm{ml} / \mathrm{h}$. Nickel recovery has been also investigated using hydrochloric acid as an eluent with and without electric current enhancement.

Acknowledgments The authors wish to acknowledge all who supported this work.

\section{References}

Adams R, Hudson M (1991) Reversible extraction of ionic species using electrochemically assisted ion exchange. Solvent Extr Ion Exch 9(3):497-513. doi:10.1080/07366299108918067

Aguilar-Gonzalez M, Gorokhovsky A, Aguilar-Elguezabal A (2010) Removal of lead and nickel from aqueous solutions by $\mathrm{SiO}_{2}$ doped potassium Titanate. Mater Sci Eng, B 174(1-3):105-113. doi:10.1016/j.mseb.2010.03.057

Ahmed Basha C, Ghosh PK, Gajalakshmi G (2008) Total dissolved solids removal by electrochemical ion exchange (EIX) process. Electrochim Acta 54(2):474-483. doi:10.1016/j.electacta.2008. 07.040 
Akbal F, Camci S (2011) Copper, chromium and nickel removal from plating wastewater by electrocoagulation. Desalination 269(1-3): 214-222. doi:10.1016/j.desal.2010.11.001

Alyuz B, Veli S (2009) Kinetics and equilibrium studies for the removal of nickel and zinc from aqueous solutions by ion exchange resins. J Hazard Mater 167(1-3):482-488. doi: 10.1016/j.jhazmat.2009.01.006

Bhatnagar A, Minocha A (2010) Biosorption optimization of nickel removal from water using Punica granatum peel waste. Colloids Surf, B 76(2):544-548. doi:10.1016/j.colsurfb.2009.12.016

Borbely G, Nagy E (2009) Removal of zinc and nickel ions by complexation-membrane filtration process from industrial wastewater. Desalination 240(1-3):218-226. doi:10.1016/j.desal.2007. 11.073

Bridger NJ, Jones C, Neville M (2007) Electrochemical ion exchange. J Chem Technol Biotechnol 50(4):469-481. doi:10.1002/jctb. 280500405

Channarong B, Lee S, Bade R, Shipin O (2010) Simultaneous removal of nickel and zinc from aqueous solution by micellarenahnced ultrafiltration and activated carbon fiber hybrid process. Desalination 262(1-3):221-227. doi:10.1016/j.desal. 2010.06.016

Coletta T, Bruell C, Ryan D, Inyang H (1997) Cation-Enhanced Removal of Lead from Kaolinite by Electro kinetics. J Environ Eng 123(12):1227-1233. doi:10.1061/(ASCE)0733-9372(1997) 123:12(1227

Cumming I, Tai H, Beir M (1997) A model to predict the performance of an electrochemical ion exchange cell. Chem Eng Res Des 75(1):9-13. doi:10.1205/026387697523336

Dermentzis K (2010) Removal of nickel from electroplating rinse waters using electrostatic shielding electrodialysis/electrodeionization. J Hazard Mater 173(1-3):647-652. doi:10.1016/j.jhazmat. 2009.08.133

Ewecharoen A, Thiravetyan P, Nakbanpote W (2008) Comparison of nickel adsorption from electroplating rinse water by coir pith and modified coir pith. Chem Eng J 137(2):181-188. doi:10.1016/ j.cej.2007.04.007

Forstner U, Wittman GT (1979) Metal pollution in aquatic environment. Springler, Berlin

Fujii Y, Abdul Matin MD, Ismail I, Nomura M (1998) Isotope effects in electron exchange system. In: Proceedings of the sixth International workshop on the separation phenomena in liquids and gases, Nagoya, Japan

Gonzalez R, Cerpa A, Alguacil F (2010) Nickel (II) removal by mixture of Acorga M5640 and DP8R in pseudo-emulsion based hollow fiber with strip dispersion technology. Chemosphere 81(9):1164-1169. doi:10.1016/j.chemosphere.2010. 08.054

Halle K, Fischwasser K, Fenk B (1982) Recovery of metals from electroplating wastes. Technol. Umweltschutz 25:120-132

Henry P, Van Lierde A (1998) Selective separation of vandium from molybdenum by electrochemical ion exchange. Hydrometallurgy 48(1):73-81. doi:10.1016/S0304-386X(97)00060-1

Ismail IM, Nomura M, Fujii Y (1997a) Europium isotope effects in ligand exchange system and electron exchange system. In: Proceedings of the 1997 Fall Meeting of the Atomic Energy Society of Japan

Ismail IM, El-Sourougy MR, Abdel Moneim N, Aly HF (1997b) Separation of caesium and cobalt from contaminated waste water using potassium nickel hexacyanoferrate complex. In: Proceedings of the International Symposium on Future Issues of Research on Science and Technology-First' 97 , ISSN: 0883-8692, Tokyo, Japan
Ismail IM, Nogami M, Suzuki K, Ikeda Y (2001) Development of diamide resin for treatment of radioactive liquid waste (2) adsorption properties of TMMA resin for U(VI) and $\mathrm{Ce}(\mathrm{III})$. In: Fall Meeting of the Atomic Energy Society of Japan

Ismail IM, Md Abdul Matin, Nomura M, Fujii Y (2002) Isotope Effects of Copper in $\mathrm{Cu}(\mathrm{II})$ Ligand-Exchange Systems by Ion Exchange Chromatography. Journal of Ion Exchange 13(2):40

Kabadasli I, Arslan T, Olmez-Hanci T, Arslan-Alaton I, Tunay O (2009) Complexing agent and heavy metal removals from metal plating effluent by electrocoagulation with stainless steel electrodes. J Hazard Mater 165(1-3):838-845. doi:10.1016/ j.jhazmat.2008.10.065

Kandah M, Meunier J (2007) Removal of nickel ions from water by multi-walled carbon nanotubes. J Hazard Mater 146(1-2): 283-288. doi:10.1016/j.jhazmat.2006.12.019

Karate V, Marathe K (2008) Simultaneous removal of nickel and cobalt from aqueous stream by cross flow micellar enhanced filtration. J Hazard Mater 157(2-3):464-471. doi:10.1016/ j.jhazmat.2008.01.013

Katsou E, Malamis S, Haralambous K, Loizidou M (2010) "Use of ultrafiltration membranes and aluminosilicate minerals for nickel removal from industrial wastewater". J Membr Sci 360(1-2): 234-249. doi:10.1016/j.memsci.2010.05.020

Li C, Champagne P (2009) Fixed-bed column study for the removal of cadmium (II) and nickel (II) ions from aqueous solutions using peat and mollusk shells. J Hazard Mater 171(1-3):872-878. doi:10.1016/j.jhazmat.2009.06.084

Miao Li M, Feng C, Zhang Z, Zhao R, Lei X, Chen R, Sugiura N (2009) Application of an electrochemical-ion exchange reactor for ammonia removal. Electrochim Acta 55(1):159-164. doi: 10.1016/j.electacta.2009.08.027

Njau N, Woude M, Visser G, Janssen L (2000) Electrochemical removal of nickel ions from industrial wastewater. Chem Eng $\mathrm{J}$ 79(3):187-195. doi:10.1016/S1385-8947(00)00210-2

Nogami M, Ismail IM, Suzuki K, Ikeda Y (2001) Development of diamide resin for treatment of radioactive liquid waste (1) concept of development and synthesis of TMMA resin. In: Fall Meeting of the Atomic Energy Society of Japan

Ozturk A (2007) Removal of nickel from aqueous solution by the bacterium Bacillus thuringiensis. J Hazard Mater 147(1-2): 518-523. doi:10.1016/j.jhazmat.2007.01.047

Popuri S, Vijaya Y, Boddu V, Abburi K (2009) Adsorptive removal copper and nickel ions from water using chitosan coated PVC beads. Bioresour Technol 100(1):194-199. doi:10.1016/ j.biortech.2008.05.041

Pospisil M, Kovarik P, Cuba V, Mucka V (2008) Removal of nickel and cobalt ions from aqueous solutions using electron-beam treatment. Radiat Phys Chem 77(8):968-973. doi:10.1016/ j.radphyschem.2008.03.005

Rengaraj S, Kyeong-Ho Y, Seung-Hyeon M (2001) Removal of chromium from water and waste water by ion exchange resin. J Hazard Mater 87(1-3):273-287. doi:10.1016/S0304-3894(01)00291-6

Sun L, Miznikov E, Wang L, Adin A (2009) Nickel removal from waste water by electroflocculation-filtration hybridization. Desalination 249(2):832-836. doi:10.1016/j.desal.2009.01.040

Turner AD, Dozol JF, Gerontopoulos P (1989) Electrochemical and Ion-exchange Processes, Commission of the European Communities-EUR. Cambridge Univ. Press, Great Britain

Vieria MGA, Almeida Neto AF, Gimenes ML, da Silva MGC (2010) Removal of nickel on Bofe bentonite calcined clay in porous bed. J of Hazard Mater 176(1-3):109-118. doi:10.1016/j. jhazmat.2009.10.128 
Yansheng Li, Yongbin Li, Liu Z, Wu T, Tia Y (2011) A novel electrochemical ion exchange system and its application in water treatment. J of Environ Sci 23:S14-S17. doi:10.1016/S10010742(11)61069-3
Ren Y, Yan N, Wen Q, Fan Z, Wei T, Zhang M, Ma J (2010) Graphene/ $\delta-\mathrm{MnO}_{2}$ composite as adsorbent for the removal of nickel ions from wastewater. Chem Eng $\mathrm{J}$ (in press), Corrected Proof doi:10.1016/j.cej.2010.08.010 